\title{
The rise of China and the US-Europe alliance drift in the 2010s: A lost decade for the European Union?
}

\author{
El ascenso de China y la deriva de la alianza entre Estados Unidos \\ y Europa en el decenio del 2010: \\ ¿una década perdida para la Unión Europea?
}

Antonio José Pagán Sánchez

$\mathrm{PhD}$ candidate in International Relations at Nankai University

antoniomurcia9@gmail.com

Summary: I. Introduction.-II. The Asian Infrastructure Investment Bank.-III. The Belt and Road Initiative.-IV. The deployment of Huawei's 5G networks. - V. China as a threat within NATO's framework.-VI. Conclusion.

\begin{abstract}
The United States and its allies within the European Union have been unable to forge a common response to deal with the rise of China. Even though China's growing global presence might undermine the international position of the United States, Washington's European allies have sometimes refused to close ranks with their American ally. And more importantly, European engagement with China during the last decade has lacked internal consistency and cohesion, to the point that the European Union has rarely been the relevant actor when it comes to shaping Europe-China relations. This is the conclusion reached by this paper after analyzing the EU's behavior on the Asian Infrastructure Investment Bank, the Belt and Road Initiative, the adoption of Huawei's 5G technology and the consideration of China as a threat within NATO's framework. The European Commission has been unwilling or unable to unite the member states around a common position on these four cases. However, the findings of this article also support the idea that an embryonic model of strategic autonomy was already underway during the last decade, and that the growing awareness within the EU about the importance and implications of China's rise brings new geopolitical opportunities for the union.

Keywords: China, power transition, transatlantic relationship, strategic autonomy, alliance drift.
\end{abstract}

Resumen: Estados Unidos y sus aliados dentro de la Unión Europea han sido incapaces de forjar una postura común al lidiar con China. Aunque la creciente presencia global de China podría socavar la posición internacional de Estados Unidos, los aliados europeos de Washington han rechazado en ocasiones cerrar 
filas con su aliado americano. Y lo que es más importante, la relación europea con China durante la última década ha carecido de consistencia interna y cohesión, hasta el punto de que la Unión Europea ha sido raramente "el" actor relevante a la hora de dar forma a la relación entre Europa y China. Esta es la conclusión alcanzada por el presente artículo tras analizar el comportamiento de la UE en el Banco Asiático de Inversión en Infraestructuras, la Nueva Ruta de la Seda, la adopción de la tecnología $5 G$ de Huawei y la consideración de China como una amenaza dentro del marco de la OTAN. La Comisión Europea no ha podido o querido unir a todos los estados miembros en torno a una postura común en estos cuatro casos. Sin embargo, los resultados del presente artículo también corroboran la idea de que un modelo embrionario de autonomía estratégica ya se había puesto en marcha durante la última década, y que la creciente concienciación dentro de la UE sobre la importancia y las implicaciones del ascenso de China proporcionan nuevas oportunidades geopolíticas para la Unión.

Palabras clave: China, transición de poder, relación transatlántica, autonomía estratégica, deriva de la alianza. 


\section{Introduction}

December 1978. Deng Xiaoping becomes the paramount leader of the People's Republic of China during the Third Plenum of the $11^{\text {th }}$ Central Committee Congress of the Communist Party of China. His accession to power marked the beginning of the reform and opening-up policy that, through the next four decades, would result in the fastest process of economic growth and development in China's history. And throughout this period, in spite of some occasional diplomatic clashes, the Chinese government was assisted by the United States, which for years encouraged Beijing to play a more active role in international affairs and supported its bid for accession to the World Trade Organization (WTO). Successive governments in the United States cooperated economically with China on the basis that this would, in the medium to long term, make this Asian country increasingly similar to those of the liberal world, including the eventual adoption of liberal democracy. But these expectations, as is evident, have not been fulfilled.

Washington's policy towards China over the past four decades has ended up, in stark contrast to its initial objectives, placing at the top of the international system a country whose political regime is completely different in terms of ideological values from that of the current hegemonic power, the United States. The ideological principles of the liberal international order and the international position of the United States are under increasing criticism from China's state media ${ }^{1}$, as part of a strategy that, given the enormous difficulty of proposing an ideologically alternative international order, seeks to turn the existing liberal one into an "agnostic" one ${ }^{2}$. A new order in which democratic and liberal values are not privileged and do not justify foreign interference in the internal affairs of third countries.

In view of the systemic challenge that the rise of China poses, in both ideological and material terms, to the international position of the United States and the liberal international order it leads, Washington policymakers have attempted over the past decade to resort to the US-led system of alliances to maintain and strengthen the global position of the hegemonic

${ }^{1}$ See, for example, Fabio Massimo Parenti, "Positive New Consensus on China Emerging in EU", Global Times, April 14, 2020, https://www.globaltimes.cn/content/1185590. shtml (Accessed June 14, 2021), and Global Times Editorial, "Immoral to boost reelection by attacking WHO: Global Times editorial”, Global Times, April 15, 2020, https://www.globaltimes.cn/content/1185734.shtml (Accessed June 14, 2021).

2 Kyle Lascurettes, Orders of Exclusion: Great Powers and Strategic Sources of Foundational Rules in International Relations (New York: Oxford University Press, 2020), 238241. 
power. This is not surprising, as the alliance system is the only area of power in which China is unable to match the United States in the short, medium, or even long term. Twelve of the 20 largest economies in the world are allies of the United States, and combined with this country, accounted for more than half of the world's Gross domestic product (GDP) in $2019^{3}$. Meanwhile, China has historically refused to establish alliances with third countries. Its only official ally is North Korea, and Chinese leaders are wary of implementing a policy of alliances that, although it could increase their international influence, is seen as a potential burden ${ }^{4}$.

Closing ranks with its allies around a common stance on China could certainly serve well the interests of the United States in a possible moment of power transition, especially through an effective multilateralism that, according to Keohane, consists of "the practice of coordinating national policies in groups of three or more states, through ad hoc arrangements or by means of institutions" 5 . The implementation of a common policy on China could also, above all, keep US allies away from those Chinese initiatives that reinforce Beijing's international position while undermining that of Washington. The problem, however, arises with the realization that US allies are increasingly interdependent with China, and therefore that they are often reluctant to adopt measures that could jeopardize their bilateral relationship with Beijing. This trend is already having a direct impact on the very relationship between the United States and its allies, especially after the mid2010s. Recent academic literature has already analyzed the dilemma faced by traditional US allies such as Australia ${ }^{6}$, South Korea ${ }^{7}$ and the Southeast Asian nations ${ }^{8}$, which are trapped into the new dynamics of great power

3 The 12 US allies among the top 20 largest economies are Japan, Germany, the United Kingdom, France, Italy, Brazil, Canada, the Republic of Korea, Australia, Spain, the Netherlands, and Turkey.

${ }^{4}$ Zhenming Zhong and Yanqi Yang, "Alliance Forging or Partnership Building? China's Policy in the Asia-Pacific under the Xi Administration”, The International Spectator 55, no. 1 (2020): 62-64.

${ }^{5}$ Robert O. Keohane, "Multilateralism: an agenda for research", International Journal 45, no. 4 (1990): 731.

${ }^{6}$ Nicholas Thomas, "The Economics of Power Transitions: Australia between China and the United States", Journal of Contemporary China 24, no. 95 (2015): 846-864; John Blaxland, "Strategic Balancing Act Australia's Approach to Managing China, the USA and Regional Security Priorities”, Security Challenges 13, no. 1 (2017): 19-40.

7 Woosang Kim, "Rising China, pivotal middle power South Korea, and Alliance transition theory", International Area Studies Review 18, no. 3 (2015): 251-265.

8 Jonathan Stromseth, DON'T MAKE US CHOOSE. Southeast Asia in the throes of US-China rivalry (Washington, The Brookings Institution, 2019); Sung Chul Jung, "Lonely China, Popular United States: Power Transition and Alliance Politics in Asia", Pacific Focus 33, no. 2 (2018): 260-283. 
rivalry and that, dependent on Beijing in economic issues and on Washington in security affairs, are unwilling to take sides.

The European region is no exception to this alliance drift phenomenon, despite the fact that there is a lack of academic studies that analyze the rise of China as a factor behind this process. Encouraged by the potential economic benefits, the vast majority of the member states of the European Union (EU) have not hesitated at times to take a different stance than their American ally in their relations with China. The United States has tried to keep them away from some of the Chinese initiatives launched during the last decade, but has not always succeeded in this endeavor. Whether the United States manages to get its European allies on its side has already become a crucial factor in its rivalry with China, and not only in terms of balance of power. After all, the symbolism of European support for the global leadership of the United States is evident, given that as Mazarr has argued, Europe has been for decades at the core of the "guiding coalition" that established the norms, institutions, and practices of the liberal international order ${ }^{9}$.

However, over the past decade, the member states of the EU have engaged with Beijing in ways that have not always pleased Washington's policymakers, given that this autonomous foreign policy has reinforced China's international influence. In this regard, what has been the role of the European Union in the unfolding of events? This paper aims to provide an answer to this question. The findings of this article indicate that, although the ideal option for the member states of the EU, and for the Union itself, would have been to act in a joint manner to strengthen their position in dealing with China, this has not been the case, and that the EU has played a rather limited role during all this time. This conclusion is reached after analyzing the role of the EU in the four most relevant international cases for the balance of power between the United States and China during the last decade in terms of influence in financial institutions, geopolitical power, technological primacy, and military capabilities, respectively: the Asian Infrastructure Investment Bank (AIIB), the Belt and Road Initiative (BRI), the deployment of Huawei's 5G technology, and the consideration of China as a military threat within the North Atlantic Treaty Organization's framework. In half of the cases, the European Commission did not attempt to forge a common response, and when it tried, it failed to do so. However, these failures, together with China's increasingly assertive foreign policy, have also convinced the EU to face the new decade with a much more geopolitically oriented approach.

9 Michael J. Mazarr, "Summary of the Building a Sustainable International Order Project", Rand Corporation (2018): 4. 


\section{The Asian Infrastructure Investment Bank (AIIB)}

The AIIB was founded in 2014 in an international conference held in Beijing and attended by political authorities from 21 Asian countries. The new bank, which was a key part of Beijing's strategy announced by Xi Jinping in 2015 to create a new "regional order" ${ }^{10}$, reflected a tectonic shift in China's foreign policy that would become especially evident over the next few years: China would not only react to the initiatives proposed by third countries, but would also present its own international projects.

The establishment of the AIIB could help China achieve some domestic gains, such as the creation of new job opportunities, the alleviation of the overcapacity problem of some industries, and the expansion of its geopolitical presence in a region that is often the scene of territorial and maritime disputes ${ }^{11}$. Nevertheless, China's dissatisfaction with the distribution of voting power in the major international financial institutions was also a key factor that encouraged Chinese leaders to establish the AIIB. When the AIIB was established in 2014, China held a voting power of $3,99 \%$ in the International Monetary Fund (IMF) ${ }^{12}, 4,42 \%$ in the World Bank $^{13}$, and $5,44 \%$ in the Asian Development Bank (ADB) ${ }^{14}$. Or in other words, China's voting power was far below the real size of its economy, which in 2014 accounted for 16,07\% of global GDP in terms of purchasing power parity ${ }^{15}$. The reluctance of the US Congress to pass a reform of the IMF's voting power only added to China's sense of grievance. In this context, the creation of a new multilateral development bank in which China would be the majority partner was considered as an acceptable unilateral decision to correct the situation.

10 Joanna Chiu, "Xi calls for 'new regional order"”, Bangkok Post, March 28, 2015, https://www.bangkokpost.com/business/511042/xi-outlines-new-regional-order (Accessed June 17, 2021).

11 Antonio José Pagán Sánchez, "Una aproximación al Banco Asiático de Inversión en Infraestructura desde la óptica de la política exterior china”, Jiexi Zhongguo 21: 96.

12 Amanda Mars, "EEUU empantana la reforma del FMI", El País, April 12, 2014, https://elpais.com/economia/2014/04/12/actualidad/1397320660_917615.html (Accessed June 22, 2021).

13 Zhiming Xin, "China gains more say in World Bank", China Daily, April 27, 2010, https://www.chinadaily.com.cn/business/2010-04/27/content_9778666.htm (Accessed June 22, 2021).

14 Asian Development Bank, “Annual Report 2018”, ADB, December 31, 2018, https:// data.adb.org/sites/default/files/ar2018-oi-appendix1.pdf (Accessed June 22, 2021).

15 C. Textor, "China's share of global gross domestic producto (GDP) adjusted for purchasing-power-parity (PPP) from 2010 to 2020 with forecasts until 2026”, Statista, June 22, 2020, https://www.statista.com/statistics/270439/chinas-share-of-global-gross-domestic-product-gdp/ (Accessed June 22, 2021). 
The establishment of the AIIB strengthened China's financial influence in the Asian region, while undermining that of the United States. Whereas Washington's cumulative voting power in multilateral development banks in Asia (including the World Bank and the ADB) was 14,1\% before the establishment of the AIIB, this figure decreased to $11,2 \%$ after the foundation of the new bank, and China's cumulative voting power increased from $5,3 \%$ to $9,6 \%{ }^{16}$. Not surprisingly, the Chinese initiative was regarded with suspicion by the US government from the very beginning, given its potential to become a challenge to the international position of the United States in Asia as well as to the World Bank, the IMF and the ADB. Moreover, the Barack Obama administration held security concerns about the hypothetical indirect control of the AIIB by the Chinese government and the potential undermining of the environmental and social standards of other multilateral development banks by the acceptance of projects that would be rejected by them, spurring "a race to the bottom"17.

To the dismay of US policymakers, the majority of EU member states did not share these concerns, and on the contrary, they considered that the best way to ensure that they could influence the AIIB's regulatory evolution and its operations was to join it. It was the United Kingdom, the closest historical ally of the United States in the region, the first European country that announced its willingness to join the bank as a founding member, on March 12, 2015. This decision was heavily criticized by the Barack Obama administration, which complained that London only gave Washington 24 hours' notice of its decision to join the AIIB ${ }^{18}$. The United Kingdom's announcement was a turning point that eventually resulted in the transformation of a bank of regional scope into a global institution: when the British decision was made public, most member states of the Organization for Economic Cooperation and Development (OECD) decided to join the AIIB in less than a month ${ }^{19}$. There was a similar response from the EU member states, to the point that most of them decided to take part in the Chinese initiative.

${ }^{16}$ Scott Morris and Mamoru Higashikokubaru, "AIIB Voting Power: How Does It Compare to the other MDBs and What Does it Mean for the US and Japan?", Center for Global Development, July 9, 2015, https://www.cgdev.org/blog/aiib-voting-power-how-does-it-compare-other-mdbs-and-what-does-it-mean-us-and-japan (Accessed June 23, 2021).

${ }^{17}$ Gisela Grieger, "Asian Infrastructure Investment Bank: How lean, clean and green is the AIIB?", European Parliamentary Research Service - PE 679.086 (2021): 3.

18 Doug Stokes, "Trump, American hegemony and the future of the liberal international order", International Affairs 94, no. 1 (2018): 148.

19 Stephan Haggard and Jason Kuo, "The British Role in the Founding of the AIIB", Peterson Institute for International Economics, February 3, 2016, https://www.piie.com/blogs/ north-korea-witness-transformation/british-role-founding-aiib (Accessed June 23, 2021). 


\section{Figure 1}

EU member states' participation in the AIIB

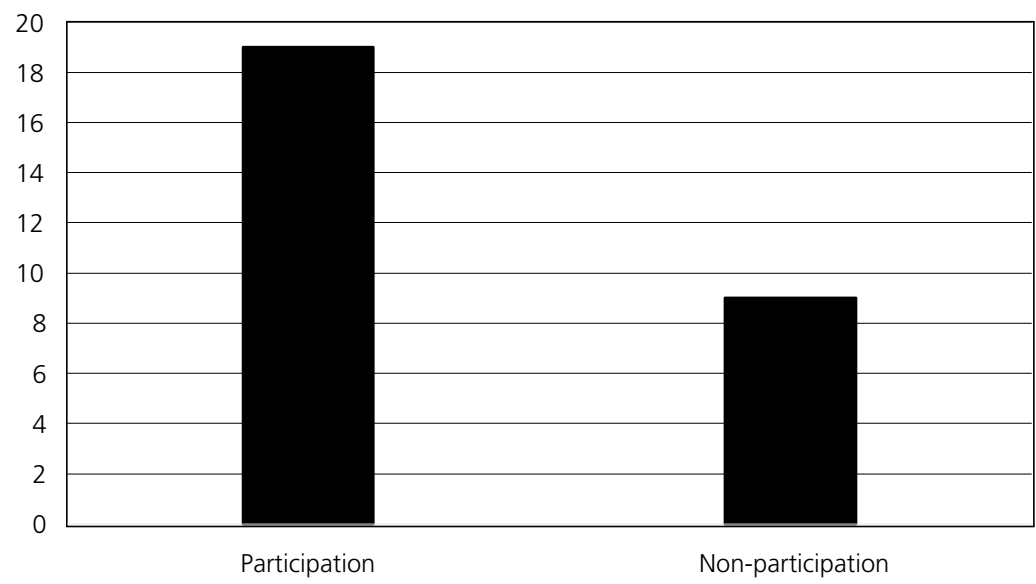

Source: author's own creation.

Of the 28 member states that the EU had in 2015, 19 decided to join the AIIB, while 9 of them declined to do $\mathrm{so}^{20}$. There was no unity of action among these 28 countries when it came to making a decision on their participation in the Chinese initiative, losing an opportunity to assert their interests jointly. Paradoxically, the most repeated message among the major European capitals was that participation in the AIIB would make it possible to shape its future evolution and favor its adoption of high standards of governance. For example, the then Germany's finance minister Wolfgang Schäuble, after announcing Berlin's decision to join the AIIB, stated, "we want to contribute our long-standing experience with international financial institutions to the creation of a new bank by setting high standards and helping the bank to get high international reputation" 21 .

Admittedly, the Chinese government granted Western countries the capacity to exert influence within the operations and the evolution of the

20 The EU member states that joined the AIIB are Austria, Belgium, Denmark, Finland, France, Germany, Greece, Hungary, Ireland, Italy, Luxembourg, Malta, the Netherlands, Poland, Portugal, Romania, Spain, Sweden and the United Kingdom. The full list of AIIB members can be accessed in the following source: Asian Infrastructure Investment Bank, "Members and Prospective Members of the Bank", AIIB, June 7, 2020, https://www.aiib.org/en/ about-aiib/governance/members-of-bank/index.html (Accessed June 24, 2021).

${ }^{21}$ Ian Tsung-yen Chen, Configuring the Asian Infrastructure Investment Bank: Power, Interests and Status (New York: Routledge, 2021), 140. 
bank. Knoerich and Urdinez have even claimed that most Western countries joined the bank precisely because they were encouraged by Beijing through the inducement of agency in certain aspects such as its founding membership and its articles of agreement ${ }^{22}$. Yet, if what they really wanted was to influence the development of the AIIB, and not to ingratiate themselves with the Chinese government, as the US government heavily criticized, it is striking that 19 EU member states decided to join the bank in a unilateral and haphazard manner, without exercising unity of action.

The role of the European Commission in the accession of the $19 \mathrm{EU}$ member states to the AIIB was next to nil. As Bustillo and Maiza have argued, this European institution complained about the unilateral decision of these countries to join the bank, as well as their omission of EU interests by not requesting representation for European institutions within the bank, as was the case, for example, with the European Bank for Reconstruction and Development. According to both authors, the possibility of implementing a joint EU response was briefly explored in 2015 by the Economic and Financial Committee, but its adoption became impossible after the unilateral decision of the United Kingdom to join the AIIB as a founding member on March 12, 201523.

The AIIB case reflected the difficulty of achieving a common position among the EU member states when dealing with China. However, the BRI case is even more paradigmatic. While the European Commission did not earnestly seek to forge a common response on the AIIB, it did attempt to do so with the BRI. In that context, the competing interests among EU member states and the limits of the union to become the key political actor in dealing with China would then emerge.

\section{The Belt and Road Initiative (BRI)}

The BRI was announced by Xi Jinping in Kazakhstan during a speech at Nazarbayev University in September 2013. The initiative, to which China has pledged to allocate $\$ 1.25$ trillion by 2025 , plans to build infrastructure routes by land and sea that connect the Eurasian region and also reach the African continent. Most BRI's infrastructure projects extend

22 Jan Knoerich and Francisco Urdinez, "Contesting Contested Multilateralism: Why the West Joined the Rest in Founding the Asian Infrastructure Investment Bank", The Chinese Journal of International Politics 12, no. 3 (2019).

${ }^{23}$ Ricardo Bustillo and Maiza Andoni, "China, the EU and multilateralism: the Asian Infrastructure Investment Bank”, Revista Brasileira de Política Internacional 61, no. 1 (2018): 10 . 
throughout Southeast Asia, Central Asia, the Middle East, and Europe. These four regions are critical for the international position of the United States, given that most of its allies are located within them, as well as $70 \%$ of the world's population, $55 \%$ of global GDP, and $75 \%$ of the world's energy reserves ${ }^{24}$.

The BRI has eventually become a diplomatic success for China. 140 countries have signed a Memorandum of Understanding with China to officially become members of the initiative ${ }^{25}$. And, as Europe was regarded by China as the final destination of the BRI, the EU could not afford to stay on the sidelines. In fact, the initiative presented both evident economic opportunities and challenges for the union itself from the very beginning. A study by the think tank Bruegel estimated that the BRI could increase the EU's foreign trade by $6 \%$. Besides, with the estimated creation of $\$ 2.5$ trillion in trade among BRI countries between 2015 and 2025, and the number of their middle-class citizens reaching 2 billion by $2050^{27}$, the Chinese initiative had, from the outset, the potential to increase European exports to Asia, to which should also be added the opportunities for economic growth on European soil provided by Chinese investments in infrastructure in the region. Moreover, the BRI was also regarded as a positive element in terms of financial diversification, in a moment in which economic actors, such as sovereign wealth funds, non-European banks and the IMF had increased their leverage over the financing of European economies after the global financial crisis of $2008^{28}$.

Nevertheless, in spite of the economic opportunities posed by the BRI, the initiative was received with suspicion by the European Commission and some EU member states. In a speech in 2017 at the $12^{\text {th }}$ EU-China Business Summit, the then President of the European Commission Jean-Claude Juncker, after acknowledging the potential economic benefits brought by the Chinese initiative, stated in the presence of China's Premier Li Keqiang

24 Álex Rodríguez, "China, la Nueva Ruta de la Seda”, La Vanguardia Dossier 60 (2016): 3 .

${ }^{25}$ The list of BRI members can be found at the following source: Christoph Nedopil, "Countries of the Belt and Road Initiative", Green Belt And Road Initiative Center, January, 2021, https://green-bri.org/countries-of-the-belt-and-road-initiative-bri/?cookie-statechange $=1624387601648$ (Accessed June 28, 2021).

${ }^{26}$ Stephan Barisitz and Alice Radzyner, "The New Silk Road, part II: implications for Europe", Focus on European Economic Integration Q4 (2017).

27 Yiwei Wang, "One Belt One Road: Opportunities for Europe-China cooperation", Friends of Europe, May 13, 2015, https://www.friendsofeurope.org/insights/one-belt-oneroad-opportunities-for-europe-china-cooperation/ (Accessed June 28, 2021).

28 Ramon Pacheco, “Europe's Financial Security and Chinese Economic Statecraft: the Case of the Belt and Road Initiative", Asia Europe Journal 16, no. 3 (2018): 238. 
that, when it comes to the implementation of infrastructure projects, "the rules must be the same for all", that European companies should compete on the same terms as their Chinese counterparts, and that "a level playing field" should be ensured ${ }^{29}$. In fact, the European Commission perceived the BRI as a potential challenge to the internal cohesion of the EU, given that its large amount of infrastructure projects in Eastern European countries might increase Beijing's leverage over them and turn this region into an area overly dependent on funding from China. According to this perception, the BRI would be part of a strategy of "divide and conquer", which would make it impossible for the European Union to reach a common position on China on sensitive issues, as the countries benefiting from this initiative could compete with each other for China's favor and boycott foreign policy decisions that require unanimity. In this regard, Sigmar Gabriel, former German Foreign Minister, stated in 2017 referring to European countries that "if we do not succeed in developing a single strategy towards China, then China will succeed in dividing Europe" 30 .

The hypothetical attempt to divide Europe might be favored by the direct control of some commercial and economic actors by the Chinese government, as part of an economic statecraft strategy that is defined by Norris as "state manipulation of international economic activities for strategic purposes" 31 . This potential challenge, in turn, might be exacerbated by China's numerous acquisitions of certain European critical infrastructures, as it happened with the Piraeus Port in Greece and other investments in ports located in Spain, Italy and Belgium ${ }^{32}$. Moreover, the European Commission was also concerned about the BRI's impact on the international standards of the infrastructure projects implemented on European soil. In this regard, the Article 8 of the "Directive 2012/34/ EU of the European Parliament and of the Council of 21 November 2012 establishing a single European railway area" provided that EU member states must guarantee the economic sustainability of infrastructure

29 Jean-Claude Juncker, "Speech by President Jean-Claude Juncker at the 12th EU-China Business Summit”, European Commission, June 2, 2017, https://ec.europa.eu/commission/ presscorner/detail/fr/SPEECH_17_1526 (Accessed June 30, 2021).

30 Sigmar Gabriel, "Berlin Calls for "One-Europe Policy"”, German-Foreign-Policy, September 11, 2017, https://www .german-foreign-policy.com/en/news/detail/7382/ (Accessed June 29, 2021).

31 William J. Norris, Chinese Economic Statecraft: Commercial Actors, Grand Strategy, and State Control (New York, Cornell University Press, 2018), 16.

32 We Build Value, "Europe wants its "own" New Silk Road", We Build Value, November 7, 2018, https://www.webuildvalue.com/en/global-economy-sustainability/europe-wantsits-own-new-silk-road.html (Accessed June 29, 2021). 
projects $^{33}$, which in theory was not always warranted under the BRI. As a consequence of these potential challenges, not all EU member states have decided to join the initiative.

\section{Figure 2}

EU member states' participation in the BRI

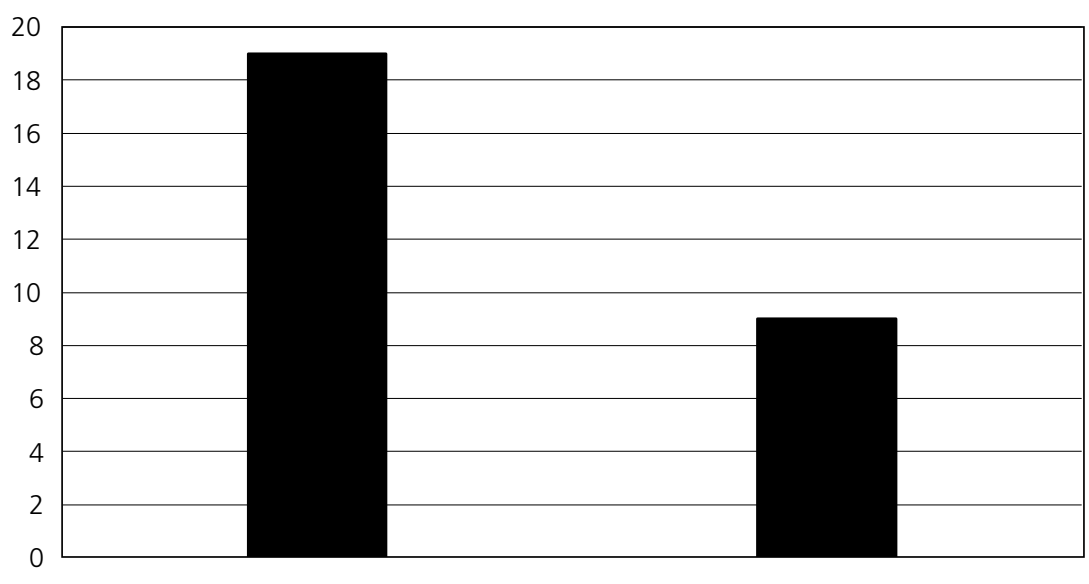

Participation

Non-participation

Source: author's own creation.

The correlation between participation and non-participation of EU member states in the BRI is exactly the same as in the case of the AIIB: 19 decided to join the BRI, whereas 9 of them declined to take part ${ }^{34}$. In spite of the potential challenges posed by the initiative to European unity, and the growing concerns raised by European authorities, the EU failed to formulate a comprehensive strategy towards the BRI that could be accepted by all member states. As with the other cases analyzed in this article,

${ }^{33}$ Directive 2012/34/EU of the European Parliament and of the Council of 21 November 2012 establishing a single European railway area Text with EEA relevance (OJ L 343, 14.12.2012, p. 32-77).

34 The EU member states that joined the BRI are Austria, Bulgaria, Croatia, Czech Republic, Estonia, Greece, Hungary, Italy, Latvia, Lithuania, Luxembourg, Malta, Poland, Portugal, Romania, Slovakia, Slovenia, and Sweden. The full list of BRI members can be accessed in the following source: Christoph Nedopil, "Countries of the Belt and Road Initiative (BRI)", Green Belt and Road Initiative Center, January 31, 2021, https://green-bri. org/countries-of-the-belt-and-road-initiative-bri/?cookie-state-change $=1624387601648$ (Accessed June 30, 2021). 
participation in this Chinese initiative depended exclusively on the individual decision of each member state. Western and Northern member states of the EU remained largely loyal to the European Commission's cautious response to the BRI, whereas the majority of Southern and Eastern European countries joined the initiative, some of them because of the economic opportunities provided by the initiative, and others, such as Hungary, Poland, the Czech Republic, Italy and Greece, also to assert their sovereignty in the midst of the tensions they had with the European Commission ${ }^{35}$.

The missed opportunity for the EU represented by the unilateral decision of its member states to participate in the BRI is exemplified by the potential implications of such a move, beyond the obvious weakening of European unity of action. In this regard, Martínez San Millán has argued that the decision of the majority of EU member states to join the BRI, which was made against the will of the European Commission, could be in conflict with Article 4 of the Treaty of Lisbon, which stipulates that the countries within the union shall assist the EU in the accomplishment of its tasks and should refrain from jeopardizing the attainment of its objectives, as well as with the Council Decision of 22 July 1974, which established a consultation procedure for cooperation agreements between member states and third countries ${ }^{36}$.

\section{The deployment of Huawei's 5 G networks}

If the AIIB was critical to the balance of power between the United States and China in terms of global in international financial institutions, and the BRI was crucial in terms of geopolitical power, the competition for the development of 5G networks is pivotal to the technological primacy in the $21^{\text {st }}$ century. In fact, the implications of this new technology are multifaceted. Its connection speed is 60 to 120 times faster than that of $4 \mathrm{G}$, fostering communication among machines and access to data by businesses, and also facilitating the emergence of smart cities, smart homes, and smart automobiles. In addition, $5 \mathrm{G}$ deployment is expected to create 3 million

35 Antonio José Pagán Sánchez, "Internal tensions and economic opportunities: explaining the heterogeneous stance of EU Member States towards the Belt and Road Initiative", Revista Electrónica de Estudios Internacionales 40 (2020): 1-18.

36 Carmen Martínez San Millán, "The Cooperation Agreements within the Belt and Road Initiative: The European Common Commercial Policy at crossroads", Deusto Journal of European Studies Special Issue 3 (2022): 59. 
jobs in the United States and 8 million jobs in China ${ }^{37}$. Due to the importance of this technology, Huawei's international prominence in the global deployment of 5G networks aroused suspicions in the Donald Trump administration, which saw the $5 \mathrm{G}$ networks of the Chinese company as a threat to the security of the United States and its allies and as a challenge to Washington's technological superiority.

As part of its trade war with China, and arguing that Huawei's products could be an espionage tool of the Chinese government, the then US President Donald Trump declared a national emergency in May 2019 to blacklist this Chinese company's technology in the United States. The decision banned the sales and use of Huawei's telecom equipment in the country, and also forced some US companies to suspend their businesses with the Chinese enterprise. Since then, the Donald Trump administration has repeatedly pressured its allies to deploy $5 \mathrm{G}$ networks provided by alternative suppliers such as Nokia or Sony Ericsson, which are outside the Chinese government's orbit. Washington's concerns about the global expansion of Huawei's 5G were evident during the speech by Mark Esper, the then US Secretary of Defense, at the Munich Security Conference: "I continue to stress to my friends in Europe [...] that America's concerns about Beijing's commercial and military expansion should be their concerns as well. [...] Reliance on Chinese 5G vendors, for example, could render our partners' critical systems vulnerable to disruption, manipulation, and espionage. It could also jeopardize our communication and intelligence sharing capabilities, and by extension, our alliances. [...] In the long run, developing our own secure 5G networks will far outweigh any perceived gains from partnering with heavily subsidized Chinese providers that ultimately answer to Party leadership" 38 . The perception of Huawei's 5G as a potential threat to the national security of the United States has remained after Joe Biden's rise to power.

Since 2020, the United States has implemented an ambitious foreign policy consisting of two complementary actions: the announcement of retaliation measures - mainly the suspension of intelligence cooperationagainst those allies that decide to deploy Huawei's 5G networks, and the provision of benefits for those that decide to rely on alternative companies. The Clean Network initiative, announced by Donald Trump in 2020, has

37 Gökhan Tekir, "Huawei, 5G Networks, and Digital Geopolitics", International Journal of Politics and Security 2, no. 4 (2020): 118-119.

${ }^{38}$ Mark T. Esper, "As Prepared Remarks by Secretary of Defense Mark T. Esper at the Munich Security Conference", U.S. Department of Defense, February 15, 2020, https://www. defense.gov/Newsroom/Speeches/Speech/Article/2085577/remarks-by-secretary-of-defensemark-t-esper-at-the-munich-security-conference (Accessed July 1, 2021). 
been a fundamental element of the US strategy to this day. This project has encouraged third countries to stay away from Huawei's 5G networks, offering in return a wide range of benefits such as the promotion of investments by US companies, digital cooperation, and collaboration in securing supply chains, telecommunications infrastructure, and intellectual property. The US strategy has been a resounding success: Huawei's 90 deals to deploy $5 \mathrm{G}$ networks in third countries dropped to only a dozen $^{39}$.

For its part, even though the dialogue on digital issues between the EU and China has lacked geopolitical connotations and has merely focused on technical issues ${ }^{40}$, the European Commission is also well aware of the implications of $5 \mathrm{G}$ networks in the fields of technology and security. In January 2020, the Network and Information Security (NIS) Cooperation Group, whose secretariat is held by the European Commission, published the so-called "Cybersecurity of 5G networks - EU Toolbox of risk mitigating measures". Even though this document does not mention Huawei by name, it advocates for the creation of a "robust framework of measures with a view to ensure an adequate level of cybersecurity of 5G networks across the EU and coordinated approaches among Member States" ${ }^{1}$. That same year, the European Commission also urged EU member states to diversify their 5G suppliers, in a veiled reference to the deployment of Huawei's 5G networks in European soil, and an EU official supported the idea of relying on Nokia and Sony Ericsson for the implementation of this technology ${ }^{42}$.

Nevertheless, in spite of the mounting concerns about the potential security implications of 5G technology, the European Commission is unable to ban the adoption of Huawei's networks at the European level as a consequence of the existing regulations. The amendment of the "Directive (EU) 2016/1148 of the European Parliament and of the Council of 6 July

39 Keith Krach, and Francis R. Fannon, "Under Secretary Keith Krach and Assistant Secretary Francis R. Fannon Briefing on Recent Travel to Central and South America", U.S. Embasy in Panama, November 24, 2020, https://pa.usembassy.gov/under-secretary-keithkrach-and-assistant-secretary-francis-r-fannon-briefing-on-recent-travel-to-central-and-southamerica/ (Accessed July 1, 2021).

40 Ian Anthony et al., "China-EU Connectivity in an Era of Geopolitical Competition", Stockholm International Peace Research Institute - Policy Paper 59 (2021): 36.

${ }^{41}$ NIS Cooperation Group, "Cybersecurity of 5G networks - EU Toolbox of risk mitigating measures", Europa.eu, March 8, 2021, https://ec.europa.eu/newsroom/dae/document. cfm?doc_id=64468 (Accessed July 2, 2021).

${ }^{42}$ Foo Yun Chee, "EU countries must urgently diversify 5G suppliers, Commission says", Reuters, July 24, 2020, https://www.reuters.com/article/us-eu-cybersecurity-5g-idUSKCN24P12T (Accessed July 2, 2021). 
2016", which is the first cybersecurity law of the European Union, might be a valid option to accomplish this endeavor, but it would require the individual approval of each of the EU member states ${ }^{43}$. In fact, this is a particularly unlikely alternative, given that the responses of EU member states towards Huawei's 5G networks have varied widely, and some of them are already implementing this technology provided by the Chinese company without restrictions.

\section{Figure 3}

EU member states' deployment of Huawei's 5G networks

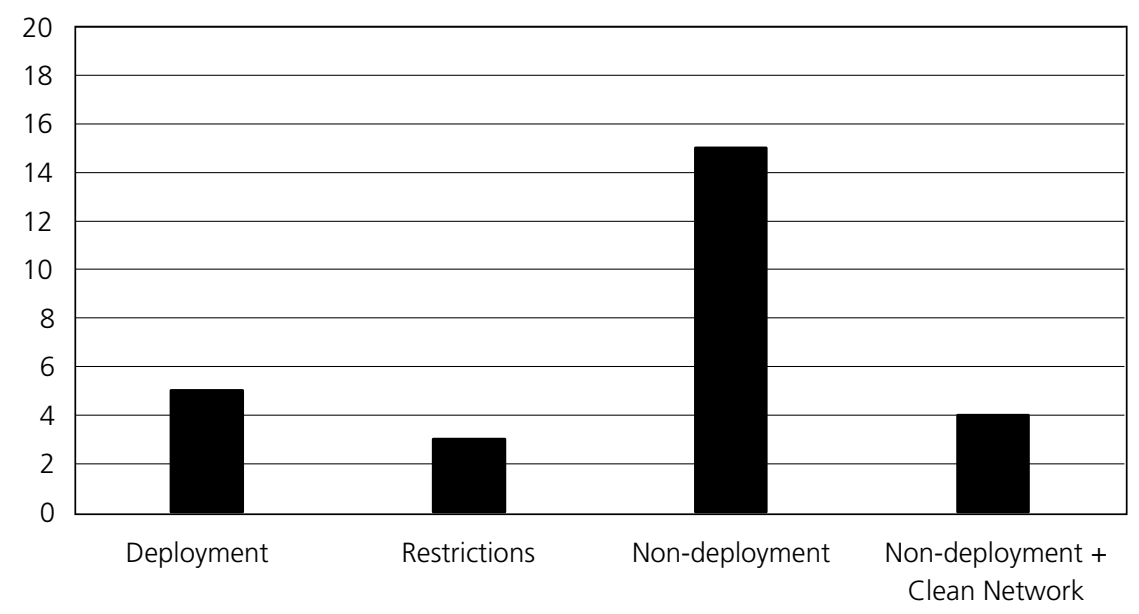

Source: author's own creation.

The response of the 27 member states of the $\mathrm{EU}^{44}$ towards the deployment of Huawei's 5G networks has been no exception to the heterogeneity with which they have engaged with China over the past decade. In this regard, five member states are implementing or planning to implement Huawei's 5G without any restrictions, three will use it with partial restrictions, 15 will not rely on this Chinese company at all, and four of

43 Robin Emmott, Foo Yun Chee, and Joanna Plucinska, "Exclusive: EU considers proposals to exclude Chinese firms from 5G networks", Reuters, January 30, 2019, https://www. reuters.com/article/uk-usa-china-huawei-tech-europe-exclusiv-idUKKCN1PO2MJ (Accessed July 2, 2021).

${ }^{44}$ At the time of making a decision on the deployment of Huawei's 5G networks, Brexit had already been implemented and the United Kingdom was no longer a member state of the EU. 
them, in addition to refusing to allow Huawei to participate in the deployment of their domestic 5G networks, have also joined the Clean Network initiative, aligning themselves squarely with the foreign policy of the United States ${ }^{45}$. Therefore, the majority position among member states has been to reject the implementation of Huawei's $5 \mathrm{G}$, but that level of rejection has varied from country to country, and the European Commission has been unable to prevent Huawei's 5G networks from being deployed on European soil.

\section{China as a threat within NATO's framework}

The North Atlantic Treaty Organization (NATO), unlike its Soviet-led counterpart during the Cold War, is a military alliance whose members have agreed to disagree, as has been evidenced repeatedly since its founding 72 years ago. Already during the discussions to establish the alliance, flexibility became the solution to solve the incompatibilities of national interests among allies, and participating countries agreed that each member of the organization would have the discretion to decide the measures to be taken in the event of military attack ${ }^{46}$.

However, the autonomy and flexibility among the members of the alliance have also meant that, at times, the United States has been unable to get its allies to serve its foreign policy interests, as was evidenced with the United Kingdom's invasion of Egypt in 1956, Charles de Gaulle's attempt to withdraw France from NATO in the 1960s and, more recently, the political tensions between Washington and some of its European allies as a consequence of the invasion of Iraq in 2003. Recent internal debates within NATO on China, in which the United States has been unable to get the unanimous support of its allies, as will be discussed below, also reflect these diverging interests and positions.

45 The EU member states that are using or planning to use Huawei's 5G networks are Austria, Hungary, Ireland, Malta, and the Netherlands. For their part, Belgium, Czech Republic and France have imposed partial restrictions on Huawei's 5G. Croatia, Cyprus, Denmark, Estonia, Finland, Germany, Italy, Latvia, Lithuania, Luxembourg, Portugal, Slovakia, Slovenia, Spain, and Sweden have refused to deploy 5G networks provided by this Chinese company. Finally, in addition to rejecting the implementation of Huawei's 5G networks, Bulgaria, Greece, Poland, and Romania have joined the Clean Network. Global responses to Huawei's $5 \mathrm{G}$ can be accessed in the following source: David Sacks, "China's Huawei Is Winning the 5 G Race. Here's What the United States Should Do To Respond”, Council on Foreign Relations, March 29, 2021, https://www.cfr.org/blog/china-huawei-5g (Accessed July 6, 2021).

46 Paul Poast, Arguing About Alliances: The Art of Agreement in Military-Pact Negotiations (New York, Cornell University Press, 2019), 147. 
China has not been a priority for NATO until very recently. In fact, since 2014, the alliance was rather focused on Russia, which was regarded as the major threat to the security of NATO members. That year, the 30 countries that are part of NATO unanimously decided to suspend all cooperation with Russia as a response to Moscow's involvement in the Ukrainian crisis and, especially, the annexation of Crimea. In fact, the United States and the European Union also took individual actions, imposing sanctions on Russian officials and businesses that resulted in the collapse of the ruble. The worsening of relations between NATO members and Russia also had another collateral effect: Russia moved closer to China, despite having numerous conflicting interests, at a time when Beijing was already displaying an increasingly proactive foreign policy.

This increasingly proactive foreign policy, consisting of seeking greater international influence and safeguarding China's national interests in an assertive way, had already aroused suspicion among EU members, 21 of which (in addition to the United Kingdom) are also part of NATO. For example, the EU attempted in 2016 to issue a critical statement on China's participation in the South China Sea conflict (which was vetoed by Hungary and Greece $^{47}$ ), in 2017 tried to adopt a critical statement on human rights in China, and in 2018, 28 out of 27 EU member states' ambassadors to China signed a critical report condemning the BRI ${ }^{48}$. Hungary's position made it impossible to achieve unanimity on the latter two issues too. Therefore, the perception of China as a potential cause for European concern was already occurring prior to 2019, and when Donald Trump tried at the 2019 London Summit of NATO to persuade US allies to declare China a threat in military terms, this negative vision was not entirely unprecedented in the West.

It was precisely at the 2019 summit when, for the first time, the members of the alliance decided to declare China as a strategic "challenge" due to its increasingly assertive foreign policy, its rising geopolitical presence, and its growing military capabilities. The heads of state and government of NATO countries stated in their joint declaration, "we recognize that China's growing influence and international policies present both opportunities and challenges that we need to address together as an Alliance" ${ }^{49}$. NATO Secretary General Jens Stoltenberg had already argued

47 Veronika Jóźwiak, "China’s Role in Hungarian Foreign Policy", The Polish Institute of International Affairs 71 (2017): 2.

48 Ravi Prasad, "EU Ambassadors Condemn China's Belt and Road Initiative", The Diplomat, April 21, 2018, https://thediplomat.com/2018/04/eu-ambassadors-condemn-chinasbelt-and-road-initiative/ (Accessed July 9, 2021).

49 North Atlantic Treaty Organization, "London Declaration. Issued by the Heads of State and Government Participating in the Meeting of the North Atlantic Council in London 
a month earlier, "as the global balance of power is shifting, it is even more important to keep your allies and friends close" 50 , and in another interview in February 2020, he argued that if the United States wants to tackle the rise of China, it will need its European allies and partners ${ }^{51}$. Donald Trump, however, tried to go further at the 2019 summit, encouraging US allies to declare China as a military challenge. But even though the mounting concerns among them on the international implications of China's rise, the then US president was unable to achieve the unanimous support of its allies.

In this regard, the consideration of China as a military threat by NATO would have strengthened the international position of the United States in a context of political crisis and trade war between Washington and Beijing since 2018. Therefore, it is not surprising that Donald Trump repeatedly pushed for such support from US allies during the 2019 summit. However, the efforts were not successful. Although the individual stance of each country was not disclosed, diplomatic sources reported that the US government's concerns were echoed by "smaller nations" in Central and Eastern Europe, but not by Western European countries. In fact, French President Emmanuel Macron stated that China should not "be the object of our collective defense... in strictly military terms" 52 .

Although the individual position of each NATO ally was not made public, all indications are that there was also no unanimity among EU member states on whether China genuinely represents a military challenge to their own internal security, given that there was a disparity of criteria between Western European countries and Central and Eastern European countries. Moreover, no attempt was made by the European institutions to get the EU member states to adopt a joint position on such a transcendental issue, which is paradoxical for two reasons. First, because even though they have gone largely undefined, the EU and NATO's opportunities of collaboration are favored by the fact that both institutions are aligned on

3-4 December 2019", NATO, December 4, 2019, https://www.nato.int/cps/en/natohq/official_ texts_171584.htm (Accessed July 9, 2021).

${ }^{50}$ Jens Stoltenberg, “'Relentless diplomacy, credible defence, strong NATO' Speech by NATO Secretary General Jens Stoltenberg on receiving the "Diplomat of the Year" award by Foreign Policy magazine", NATO, November 13, 2019, https://www.nato.int/cps/fr/natohq/ opinions_170714.htm?selectedLocale=fr (Accessed July 9, 2021).

51 Vicky McKeever, "US Needs Europe to Tackle the Rise of China, NATO Chief Says", CNBC, February 15, 2020, https://www.cnbc.com/2020/02/15/us-needs-europe-to-tackle-the-rise-of-china-nato-chief-says.html (Accessed July 9, 2021).

52 Stuart Lau, "Nato allies single out China and its policies as a strategic "challenge", South China Morning Post, December 5, 2019, https://www.scmp.com/news/china/diplomacy/article/3040666/nato-allies-single-out-china-and-its-policies-strategic (Accessed July 12, 2021). 
today's major geopolitical issues, such as counterterrorism, nuclear proliferation, the rise of China and Russia's assertiveness. The joint declarations adopted by both parts in 2016 and 2018 pledged to increase their cooperation on a wide range of issues, such as maritime operations, cybersecurity, defense capabilities, military mobility, the security of neighboring countries to the East and to the South, and also when facing external challenges such as hybrid threats ${ }^{53}$. Second, because the EU's own stance on China has evolved over the past few years, to the point of being less optimistic and incorporating security considerations into its relationship with Beijing. In March 2019, the European Commission admitted that, in Europe, "the balance of challenges and opportunities presented by China has shifted", and described the country as a "cooperation partner", a "negotiating partner", an "economic competitor", and a "systemic rival" 54 .

The lack of a joint position among the member states of the EU in NATO's internal discussions on China is a scenario that is more resembling the case of the AIIB than that of the BRI and Huawei's 5G adoption, as unlike in the latter two cases, the European Commission made no attempt to deal with China in a unified manner. This circumstance illustrates the limits of the EU's ability and, sometimes-even willingness, to shape the relationship of its member states with China. The EU has failed to become the relevant actor in Europe-China relations. However, as will be seen with the recapitulation of the main ideas of this article - as well as their implications - in the Conclusion, it would not seem accurate to argue that the period 2010-2020 has been a lost decade for the European Union when it comes to shaping this bilateral relationship.

532016 joint declaration: Donald Tusk, Jean-Claude Juncker, and Jens Stoltenberg, "Joint Declaration by the President of the European Council, the President of the European Commission, and the Secretary General of the North Atlantic Treaty Organization", European Council, July 8, 2016, https://www.consilium.europa.eu/media/21481/nato-eu-declaration-8-july-en-final.pdf (Accessed July 19, 2021); 2018 joint declaration: Donald Tusk, JeanClaude Juncker, and Jens Stoltenberg, "Joint Declaration on EU-NATO Cooperation by the President of the European Council, the President of the European Commission, and the Secretary General of the North Atlantic Treaty Organization”, European Council, July 10, 2018, https://www.consilium.europa.eu/media/36096/nato_eu_final_eng.pdf (Accessed July 19, 2021).

${ }^{54}$ European Commission, and High Representative of the Union for Foreign Affairs and Security Policy, "EU-China - A strategic Outlook", Europa.eu, March 12, 2019, https:// ec.europa.eu/info/sites/default/files/communication-eu-china-a-strategic-outlook.pdf (Accessed July 19, 2021). 


\section{Conclusion}

The EU, and in particular the European Commission, have had difficulties in forging a common European position in dealing with China, to the extent that this institution has not achieved the unanimity of the member states in any of the four cases of analysis. In two of those cases - the AIIB and the discussions to consider China as a military threat within NATO-, the European Union did not even attempt to elaborate a joint response. In view of the divergent position of the EU member states in dealing with China, it is evident that the EU is not yet the key political actor when analyzing Europe-China relations. Or in other words, a state-based approach, which takes into account the individual interests and perceptions of each one of the member states of the EU, as well as how the interplay of these two factors ends up shaping their foreign policy on China, is still essential.

Nevertheless, over the last decade, the EU has become increasingly aware of the geopolitical implications of its relationship with China, which go far beyond purely economic factors. As opposed to the initial lack of response in the case of the AIIB, which would also be the case in the discussions to consider China as a military threat within NATO's framework, it has been observed how the European Commission has progressively acquired a stronger geopolitical vision and has attempted to forge a common stance in the BRI and in the adoption of Huawei's 5G. In the latter case, moreover, it has become manifest how, despite not having the necessary tools to restrict the implementation of Huawei's 5G throughout the EU's territory, it has developed its own policy and strategy vis-à-vis this new technology, encouraging member states to ensure the security of their domestic networks. Therefore, despite the setbacks over the period 2010-2020, it is reasonable to argue that it has not been a lost decade for the EU when it comes to Europe-China relations. In fact, after a necessary reflection on the mistakes and limitations of the EU's external action during the last decade, it would not be unreasonable to expect a greater relevance of the EU in the European relationship with China during the next decade.

The attitude of the EU member states in the four cases of analysis reflects, moreover, that the recently fashionable concept of strategic autonomy, which would encompass a Europe with a more independent foreign policy and less reliant on the United States, was already a reality in the continent, at least in the second of the words that make up this buzzword. However, despite being genuinely autonomous, this policy is far from being strategic, as each member state of the EU acts on its own. The coordination of their foreign policies on China has not always existed in 
European capitals, and the European Commission has not always been able to achieve a strong, single European voice in dealing with China when it has tried.

In sum, the last decade has witnessed the awakening of a new geopolitical vision on China by the EU. As was to be expected, the process has not been without obstacles, which have made the role of the European Commission considerably challenging. Nevertheless, it remains to be seen whether these obstacles are insurmountable, given the growing awareness of the need for an increased geopolitical role of the EU in the context of the growing rivalry between the United States and China, which at times resembles a new Cold War. Events such as the recent sanctions standoff between the EU and China, the consideration of the latter not only as a partner, but also as a competitor and rival by the European Commission, the debates within the European Parliament on the Asian country, and the dispute over the ratification of the EU-China Comprehensive Agreement on Investment (CAI) certify that, unlike a decade ago, the EU is increasingly determined to approach its relationship with Beijing not only from the point of view of economic benefits and the necessary international cooperation, but also from a marked geopolitical character. Whether this "new thinking" on China, which has emerged between 2010-2020, will give way during the following decade to a period of refinement and increased vitality, in which the EU will be not only autonomous, but also strategic, only time will tell.

\section{Sobre el autor}

Antonio José Pagán Sánchez es estudiante de doctorado en Relaciones Internacionales en la Universidad de Nankai. Entre 2011 y 2015 cursó el Grado en Historia de la Universidad de Murcia, y entre 2015 y 2017 cursó el Máster en Estudios Chinos de la Universidad Pompeu Fabra. Además, entre 2017 y 2018 estudió chino nivel intermedio y avanzado en la Universidad de Nankai. Sus líneas de investigación actuales se centran en la relación triangular Europa Occidental-Estados Unidos-China, la política exterior china y las respuestas estadounidenses ante el ascenso del país asiático. Ha publicado en las revistas Relaciones Internacionales, Revista Electrónica de Estudios Internacionales (REEI) y Jiexi Zhongguo, así como en la web de Política Exterior. 


\begin{abstract}
About the author
Antonio José Pagán Sánchez is a PhD candidate at Nankai University. Between 2011 and 2015 he studied a Bachelor's Degree in History at the University of Murcia, and between 2015 and 2017 he studied a Master's Degree in Chinese Studies at Pompeu Fabra University. Besides, he studied intermediate and advanced Chinese language at Nankai University between 2017 and 2018. His current research interests are focused on the triangular relationship Western Europe-United States-China, China's foreign policy, and US responses towards the rise of this Asian country. His research has been published in the journals Relaciones Internacionales, Revista Electrónica de Estudios Internacionales (REEI) and Jiexi Zhongguo, as well as in the Politica Exterior's website.
\end{abstract}




\section{Derechos de autor}

Los derechos de autor (para la distribución, comunicación pública, reproducción e inclusión en bases de datos de indexación y repositorios institucionales) de esta publicación (Cuadernos Europeos de Deusto, CED) pertenecen a la editorial Universidad de Deusto. El acceso al contenido digital de cualquier número de Cuadernos Europeos de Deusto es gratuito inmediatamente después de su publicación. Los trabajos podrán leerse, descargarse, copiar y difundir en cualquier medio sin fines comerciales y según lo previsto por la ley; sin la previa autorización de la Editorial (Universidad de Deusto) o el autor. Así mismo, los trabajos editados en CED pueden ser publicados con posterioridad en otros medios o revistas, siempre que el autor indique con claridad y en la primera nota a pie de página que el trabajo se publicó por primera vez en CED, con indicación del número, año, páginas y DOI (si procede). Cualquier otro uso de su contenido en cualquier medio o formato, ahora conocido o desarrollado en el futuro, requiere el permiso previo por escrito del titular de los derechos de autor.

\section{Copyright}

Copyright (for distribution, public communication, reproduction and inclusion in indexation databases and institutional repositories) of this publication (Cuadernos Europeos de Deusto, CED) belongs to the publisher University of Deusto. Access to the digital content of any Issue of Cuadernos Europeos de Deusto is free upon its publication. The content can be read, downloaded, copied, and distributed freely in any medium only for non-commercial purposes and in accordance with any applicable copyright legislation, without prior permission from the copyright holder (University of Deusto) or the author. Thus, the content of CED can be subsequently published in other media or journals, as long as the author clearly indicates in the first footnote that the work was published in CED for the first time, indicating the Issue number, year, pages, and DOI (if applicable). Any other use of its content in any medium or format, now known or developed in the future, requires prior written permission of the copyright holder. 